\title{
DIGESTIBILITY OF BREWERS' GRAINS BY SWINE
}

\author{
L. Paloheimo and Berit Jahkola \\ Department of Animal Husbandry, University of Helsinki
}

Received March 9, 1959

\section{Arrangement of the experiments}

The digestion experiment was made with two young pigs (A and B) of the Large White Yorkshire breed. The animals were kept in separate concrete boxes. At the beginning of the experiment the weight of pig A was $62 \mathrm{~kg}$, and 35 days later, at the close of the experiment, $85 \mathrm{~kg}$. The corresponding figures for pig B were 56 and 75 . For a period of 3 weeks the animals were gradually accustomed to the experimental diet, which consisted of $4.4 \mathrm{~kg}$ wet brewers' grains and $6 \mathrm{~kg}$ skimmilk per day per animal. The animals were fed twice daily, at 8.00 and 18.00 . No remnants were left. After the meals the troughs were filled with fresh water.

The digestibility was determined by the $\mathrm{Cr}_{2} \mathrm{O}_{3}$ ratio technique. $\mathrm{Cr}_{2} \mathrm{O}_{3}$ was mixed in the food for 7 consecutive days. During this period samples of faeces were taken every morning. The samples of the last two days were used for the determination of the digestibility. At the beginning of the period one meal rations $(2.2 \mathrm{~kg})$ of fresh brewers' grains were weighed for the whole period and put into plastic bags which were kept in a cold room (about $\left.0^{\circ} \mathrm{C}\right)$. At each meal and for each animal $11 \mathrm{~g} \mathrm{Cr}_{2} \mathrm{O}_{3}$ was thoroughly mixed with $2.2 \mathrm{~kg}$ brewers' grains in the trough after which $3 \mathrm{~kg}$ slightly warmed skimmilk was added and mixed with it. During the preparation the animals had no access to the trough.

\section{Results}

In the evening of December 11th the animals received $\mathrm{Cr}_{2} \mathrm{O}_{3}$ for the first time with their food. The faeces collected in the following morning, 14 hours after the meal, contained already traces of the marker. The $\mathrm{Cr}_{2} \mathrm{O}_{3}$ content in the faeces in the 6 following days is shown in Table. 1. The chromium determination was made according to the principle of Palohermo and Paloheimo (9, p. 317). Beckman spektrofotometer with filter $375 m \mu$ was used. The samples of faeces collected on 17th and 18th December were analysed. The following determinations were made: 
Table 1. $\mathrm{Cr}_{2} \mathrm{O}_{3}$ content in the dry matter of faeces.

\begin{tabular}{lcc}
\hline & \multicolumn{2}{c}{$\mathrm{Cr}_{2} \mathrm{O}_{3} \mathrm{mg} / \mathrm{g}$} \\
\cline { 2 - 3 } Date & $\mathrm{Pig} \mathrm{A}$ & $\mathrm{Pig} \mathrm{B}$ \\
& & \\
\hline 12.12. & traces & traces \\
13. & 24.6 & 21.0 \\
14. & 29.5 & 35.5 \\
15. & 43.4 & 42.6 \\
16. & 40.2 & 40.8 \\
17. & 43.0 & 39.7 \\
18. & 44.3 & 42.5 \\
\hline
\end{tabular}

1) dry matter, 2) ash, 3) chromium, 4) crude protein, 5) membrane substances. The magnitude of the following fractions was obtained by calculation: 6) organic matter, 7) $\mathrm{N}$-free organic matter, 8) valuable $\mathrm{N}$-free substances. The amount of membrane substances or vegetable cell wall substances was determined by the method of Palohe imo and Paloheimo $(10$, p. 1$)$. The fraction "valuable N-free substances" is obtained by subtracting from the amount of $\mathrm{N}$-free organic matter the amount of membrane substances. The same determinations as from the faeces were made from the brewers' grains. From the skimmilk only crude protein and fat were determined in order to confirm that the composition of this product was normal. The crude fibre determination was made from the brewers' grains for the same purpose. The result of the latter determination was $16.6 \%$ of the dry matter.

Data about the composition of the brewers' grains and the faeces are given in Table 2. On the basis of these figures it is possible to calculate the digestibility of the components of the brewers' grains. In this calculation the components of the skimmilk are presumed to be completely digestible. The digestibility was calculated for each animal and for the 6th and 7th days separately. The results are shown in Table 3 .

Table 2. Data pertaining to the composition of the brewers' grains and the faeces.

\begin{tabular}{|c|c|c|c|c|c|}
\hline & \multirow{3}{*}{ 点怘 } & \multicolumn{4}{|c|}{ Faeces } \\
\hline & & \multicolumn{2}{|c|}{ Pig A } & \multicolumn{2}{|c|}{ Pig B } \\
\hline & & $\begin{array}{l}6 \text { th } \\
\text { day }\end{array}$ & $\begin{array}{l}7 \mathrm{th} \\
\text { day }\end{array}$ & $\begin{array}{r}6 \text { th } \\
\text { day }\end{array}$ & $\begin{array}{l}7 \text { th } \\
\text { day }\end{array}$ \\
\hline \multicolumn{6}{|l|}{$\%$ in $\mathrm{Cr}_{2} \mathrm{O}_{3}$-free dry matter: } \\
\hline Organic matter $\ldots \ldots \ldots \ldots \ldots \ldots$ & 96.80 & 88.20 & 88.66 & 87.71 & 88.30 \\
\hline Crude protein $\quad \ldots \ldots \ldots \ldots \ldots \ldots$ & 21.29 & 13.19 & 14.16 & 15.55 & 13.20 \\
\hline $\mathrm{N}$-free organic matter $\ldots \ldots \ldots \ldots$ & 75.51 & 75.01 & 74.50 & 72.16 & 75.10 \\
\hline Membrane substances $\ldots \ldots \ldots \ldots$. & 30.23 & 47.29 & 42.15 & 44.29 & 45.48 \\
\hline Valuable $\mathrm{N}$-free substances $\ldots \ldots$ & 45.28 & 27.72 & 32.35 & 27.87 & 29.62 \\
\hline Pro $100 \mathrm{~g} \mathrm{Cr}_{3} \mathrm{O}_{2}$-free dry matter & & & & . & \\
\hline $\mathrm{Cr}_{2} \mathrm{O}_{3} \mathrm{~g} \quad \ldots \ldots \ldots \ldots \ldots \ldots \ldots$ & 2.75 & 4.49 & 4.64 & 4.13 & 4.44 \\
\hline
\end{tabular}


Table 3. Digestibility percentages for the components of brewers' grains.

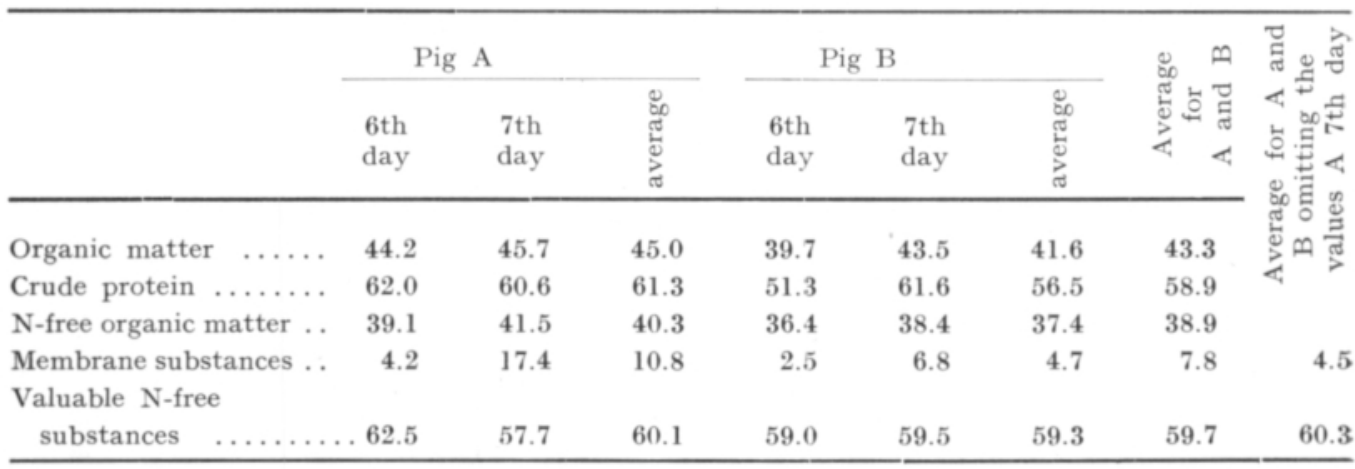

\section{Discussion}

In this investigation the traditional food analysis has not been followed. Instead of crude fibre determination, the percentage of vegetable membrane substances has been determined. The latter determination results in a group of substances which contains all the cellulose and lignin of the sample together with the major part of the hemicelluloses. The valuable $\mathrm{N}$-free substances constitute fraction of the food which results when the membrane substances are subtracted from the $\mathrm{N}$-free organic matter.

The retention time of food residues in the alimentary canal of pigs is rather short. 4 days' feeding on the experimental diet seemed to be adequate for cleaning the digestive tract of the rest of the preceding diets (Table 1). For safety's sake the samples of faeces for digestibility determinations were taken as late as on the 6th and 7 th days.

With the exception of the digestibility coefficient of membrane substances pertaining to pig $\mathrm{A}$ in the 7th day, the coefficients obtained for different animals and days are fairly well in agreement with each other and give a distinct picture of the character of brewers' grains as food for pigs.

Clawson et al. (1, p. 700), Moore (6, p. 273; 7, p. 24), and Horvath et al. $(4$, p. 869) have observed diurnal variations in the composition of swine faeces. Although these variations are not considerable, however, for obtaining a fully representative sample of faeces, it seems to be recommendable to collect the faeces produced on two consecutive days and to take an average sample from this material. In our experiments the samples were taken in the morning on two consecutive days, and each of these samples was used separately for digestibility determinations. As the morning faeces are produced partially in the preceding evening the sampling covers an appreciable part of the 24 hour period, and the samples can be considered sufficiently representative.

As mentioned above, the brewers' grains were fed together with skimmilk and the latter food was considered as totally digestible. It is evident that pigs fed on skimmilk alone still produce faeces the origin being chiefly endogenous. There is 
Table 4. Digestibility percentages of brewers' grains according to different sources.

\begin{tabular}{|c|c|c|c|c|c|}
\hline \multirow[b]{2}{*}{ According to } & \multicolumn{2}{|c|}{$\begin{array}{l}\% \text { in dry } \\
\text { matter }\end{array}$} & \multicolumn{3}{|c|}{ Digestibility \% } \\
\hline & 异芯 & 놀 & 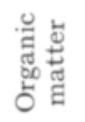 & 氙站 & 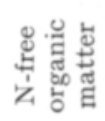 \\
\hline Table 3 (Pigs) $\ldots \ldots \ldots \ldots \ldots \ldots \ldots$ & 16.6 & 21.3 & 41.6 & 56.5 & 37.4 \\
\hline Futterwerttabellen (Pigs) $\quad \ldots \ldots \ldots \ldots$ & 19.6 & 22.1 & 45 & 73 & 36 \\
\hline Futterwerttabellen (Ruminants) $\ldots \ldots$ & 19.6 & 22.1 & 63 & 73 & 59 \\
\hline Morrison (Ruminants) $\quad \ldots \ldots \ldots \ldots \ldots$ & 15.2 & 24.1 & 64 & 73 & 61 \\
\hline Larsson et al. (Ruminants) $\ldots \ldots \ldots$ & 18.0 & 28.5 & 69 & 68 & 69 \\
\hline
\end{tabular}

no reason to suppose that in animals receiving both skimmilk and brewers'graine the endogenous production of faeces would be greater than when the animals ars fed on skimmilk alone. Further, it is reasonable to think that the said production would be of the same order when the brewers' grains are the only food. However, it is possible that the presumption of the complete digestibility of the skimmilk protein is not exactly valid. If so, the digestibility percentages of crude protein in Table 3 are too low even as percentages of apparent digestibility. As the determination of the digestibility of protein is always uncertain, this paper will chiefly pay attention to the digestibility of the N-free organic matter.

The digestibility percentages for brewers' grains in the feeding of swine are given in "Futterwerttabellen der DLG - Schweine» (3, p. 19). Table 4 shows figures which are calculated on the basis of the said paper. It contains also the average figures from table 3 . Corresponding figures for ruminants from three different sources (2, p. $43 ; 8$, p. $1046 ; 5$, p. 378$)$ are included in the same Table. It appears from Table 4 that in pigs the digestibility of organic matter and especially of N-free organic matter is appreciably inferior to that in ruminants. According to "Futterwerttabellen" the digestibility of crude protein in swine is of the same order as in ruminants. Considering the richness of cell membrane substances in brewers' grains (cf. Table 2) and the poor digestibility of these substances in pigs (cf. Table 3 ) one would expect also a poorer digestibility of crude protein. It is therefore possible that the digestibility coefficients of crude protein found in the experiment of the writers are more reliable.

Table 3 reveals the very low digestibility of membrane substances in brewers' grains when fed to pigs. This fact is in concordance with the conception of the relatively poor bacterial activity in the large intestine of the swine. On the other hand, the digestibility of valuable N-free substances seems to be rather high.

According to the results obtained in our investigation $100 \mathrm{~g}$ dry matter of brewers' grains yield to the pigs $12.0 \mathrm{~g}$ digestible crude protein and $29.4 \mathrm{~g}$ digestible $\mathrm{N}$-free organic matter. The latter amount can be divided in to $2.4 \mathrm{~g}$ digestible membrane substances and $27.0 \mathrm{~g}$ digestible valuable $\mathrm{N}$-free substances. Supposing that Morrison's coefficients for ruminants were valid for the kind of brewers' grains used 
in our experiments (cf. Table 2) the ruminants would obtain from $100 \mathrm{~g}$ brewers' grains dry matter $15.5 \mathrm{~g}$ digestible crude protein and $46.1 \mathrm{~g} \mathrm{~N}$-free organic matter. A comparison of figures presented in this paragraph yields further evidence on the inferiority of swine in making use of brewers' grains.

\section{Sum $m$ ary}

The digestion experiment was made with two young pigs. The $\mathrm{Cr}_{2} \mathrm{O}_{3}$ ratio technique was used. The diet consisted of $4.4 \mathrm{~kg}$ wet brewers' grains and $6 \mathrm{~kg}$ skimmilk per day per animal. The components of the latter food were presumed to be completely digestible. For the components of the brewers' grains the following average digestibility percentages were obtained: organic matter 43.3 ; crude protein 58.9 ; $\mathrm{N}$-free organic matter 38.9 ; membrane substances 7.8 ; valuable $\mathrm{N}$-free substances 59.7. According to different food tables the digestibility of the crude protein of brewers' grains is in ruminants $68-73 \%$, and the corresponding figure for $\mathrm{N}$-free organic matter 59-69. Comparison of the figures presented gives evidence of the inferiority of swine in making use of brewers' grains.

\section{R E F E R E N C E S.}

(1) Clawson, A. J. \& Reid, J. T. \& Sheffy, B. E. \& Willman, J. P. 1955. Use of chromium oxide in digestion studies with swine. J. Animal Sci. 14: 700-709.

(2) Futterwerttabellen der DLG. Futterwerttabellen und Bedarfsnormen für Wiederkäuer 1952. Frankfurt am Main. Arbeiten der DLG 17: 1-51.

(3) Futterwerttabellen der DLG - Schweine 1958. Frankfurt am Main. Ibid. 50: 1-31.

(4) Horvath, D. J. \& Peterson, M. E. \& Clawson, A. J. \& Sheffy, B. E. \& Loosli, J. K. 1958. Diurnal variations in the composition of swine feces. J. Animal Sci. 17: 869-874.

(5) Larsson, S. \& Olsson, N. \& JARL, F. \& Olofsson, N. E. 1951. Husdjurslära II: 1-410. Stockholm.

(6) Moore, J. H. 1957. Diurnal variations in the composition of the faeces of pigs on diets containing chromium oxide. Brit. J. Nutr. 11: 273-288.

(7) $\rightarrow$ 1958. The effect of diurnal variations in composition of the faeces of pigs on the determination of digestibility coefficients by the chromium-oxide method. Ibid. 12: $24-34$.

(8) Morrison, F. B. 1956. Feeds and Feeding. 1165 p. Ithaca, New York.

(9) Paloheimo, L. \& Paloheimo, Irja. 1935. Eine photometrische Methode zur Bestimmung der $\mathrm{Cr}_{2} \mathrm{O}_{3}$ bei Verdaulichkeitsuntersuchungen nach sog. quantitativen Indikatorverfahren. Tierernährung 7: $317-324$.

(10) - - Palohermo, IrJa. 1949. On the estimation of the total of vegetable membrane substances. J. Sci. Agric. Soc. Finland 21: 1-16. 
S E L O S T S:

\section{MÄSKIN SULAVUUDESTA SIALLA}

\section{Paloheimo ja Berit Jahkola}

\section{Yliopiston kotieläintieteen laitos, Helsinki}

Koe-eläiminä oli kaksi n. 70 kg painavaa sikaa. Mäskin ohella syötettiin kuorittua maitoa, jonka sulavuus tuloksien laskennollisessa käsittelyssä katsottiin täydelliseksi. Sulavuustutkimus suoritettiin johtoainemenetelmää käyttäen, $\mathrm{Cr}_{2} \mathrm{O}_{3}$ johtoaineena. Koetuloksista lasketut eri aineosien tai aineryhmien keskimääräiset sulavuusprosentit osoittautuivat seuraavanlaisiksi: orgaaninen aine 43,3; raakavalkuainen 58.9 ; typetön orgaaninen aine 38.9 ; kettoaineet 7.8 ; typettömät arvoaineet 59.7 . Kun märehtijöillă suoritettujen tutkimusten mukaan mäskin raakavalkuaisen sulavuusprosentti on $68-73$ ja typettömän orgaanisen aineen $59-69$, todetaan, että sika saa mäskistä sulavaa ravintoa huomattavasti vähemmän kuin märehtijät. 